\title{
PEMEROLEHAN KONJUNGSI KOORDINARIF DAN SUBORDINATIF PADA SISWA SEKOLAH DASAR
}

\author{
Roely Ardiansyah \\ Universitas Wijaya Kusuma Surabaya \\ roelyardiansyah79gmail.com
}

\begin{abstract}
ABSTRAKS
Perkembangan bahasa anak terkait dengan pemerolehan konjungsi yang dipakai atau dikuasai anak dalam kehidupan sehari-hari. Oleh karena itu, permasalahan dalam penelitian ini difokuskan pada dua masalah antara lain, (1) bagaimanakah pemerolehan konjungsi koordinatif pada anak kelas 6 Sekolah Dasar? (2) bagaimanakah pemerolehan konjungsi subordinatif pada anak kelas 6 Sekolah Dasar? Tujuan penelitian ini antara lain, (1) untuk mendeskripsikan pemerolehan konjungsi koordinatif pada anak kelas 6 Sekolah Dasar; (2) untuk mendeskripsikan pemerolehan konjungsi subordinatif pada anak kelas 6 Sekolah Dasar? Metode yang digunakan metode deskriptif kualitatif. Subjek penelitian ini adalah 11 siswa kelas 6 Sekolah Dasar berusia antara 11-12 tahun dari Sekolah Dasar Islam Darut Taqwa Surabaya. Data penelitian berupa konjungsi diperoleh di karangan (tulisan) siswa SD kelas 6 berjumlah 44. Pengumpulan data menggunakan teknik dokumentasi Teknik analisis data menggunakan teknik skala implikasional. Hasil penelitian menunjukkan bahwa siswa kelas VI memeroleh dan sering menggunakan 2 macam konjungsi dalam tulisan mereka yaitu konjungsi koordinatif dan subordinatif. Konjungsi koordinatif terdapat di karangan siswa kelas VI, meliputi sedangkan, dan, tetapi, serta, atau, kemudian. Konjungsi subordinatif terdapat di karangan siswa kelas VI, meliputi oleh karena itu, oleh sebab itu, setelah itu, yang, setelah, sesudah, sehingga, hingga, agar, supaya, ketika, sampai, walaupun, meski, maka, seperti, karena, kalau, asal.
\end{abstract}

Kata kunci: konjungsi, koordinatif, pemerolehan, subordinatif

\begin{abstract}
Child language development related to the acquisition of the conjunction used or possessed by the child in everyday life. Thus, this study is focused on two issues; (1) how does the acquisition of the coordinative conjunction in 6th grade elementary school children? (2) how does the acquisition of the subordinate conjunction in 6 th grade elementary school children? The purposes of this study cover (1) to describe the acquisition of the coordinative conjunction in 6th grade elementary school children; (2) to describe the acquisition of the subordinate conjunction in 6th grade elementary school children? The method used was qualitative descriptive method. The subjects of this research are 11 students of the 6th grade primary school ages 11 to 12 years old of Islamic primary school Darut Taqwa Surabaya. Research data about conjunction were acquired from the essay (writing) of 44 students in the 6th grade. Documentation was used as data collection technique. Data analysis used implicational scale. The results of the research showed that the most conjunctions acquired and used by the students were two types; coordinative and subordinate conjunctions. The coordinative conjunctions were sedangkan (otherwise), dan(and), tetapi (but), serta (and also), atau (or), and kemudian (then). The subordinate conjuctions were oleh karena itu (thus), oleh sebab itu(therefore), setelah itu (then), yang(which), setelah, sesudah (after), sehingga
\end{abstract}


Jurnal Belajar Bahasa, ISSN 2502-5864, E-ISSN 2503-0329

Volume 3, No. 2, September 2018

(so that), hingga (until), agar, supaya (in order to), ketika (when), sampai (until/up to), walaupun (even though), mesk (though)i, maka (so that), sepert (such as)i, karena (because), kalau, asal (if).

Keywords: acquisition, conjunction, coordinative, subordinate

\section{PENDAHULUAN}

Anakbelajar bahasa dengan berusaha memahami terlebih dahulu apa yang disampaikan dari lawan bicara. Selanjutnya, anak berusaha menjawab, tetapi terdiam sejenak karena memperhatikan isi pembicaraan dari lawan bicara. Melalui proses itu anak berusaha mengasosiasikan dan menginterpretasikan jawaban sesuai dengan apa yang didengar setelah lawan bicara selesai mengujarkan. Artinya, sebelum anak mengekspresikan diri, perasaan, pikiran, keinginan dan kebutuhannya, maka harus terkonsep terlebih dahulu dalam pikirannya. Dengan demikian, anak dikategorikan dapat berbahasa dengan baik, apabila dapat memahami sistem bahasa, maka baik atau tidaknya anak berbahasa bergantung pada faktor lingkungan atau faktor yang mempengaruhi pemakainya. Kondisi ini dapat dilihat sejauh mana perkembangan anak belajar memahami bahasa secara aktif.

Perkembangan bahasa anak disesuaikan dengan perkembangan kondisi anak memperoleh dan menggunakan bahasa untuk aktivitas sehari-hari. Jadi, tingkat penguasaan bahasa anak selalu berkembang seiring bertambahnya usia. Makin bertambah usia, makin bertambah pula pemerolehan bahasa. Pemerolehan bahasa merupakan proses penguasaan bahasa dilakukan oleh anak secara alamiah, tidak sadar, sehingga tidak ada kurikulum dan bantuan guru dalam proses pemerolehan bahasa tersebut. Pemerolehan bahasa atau language acquisition adalah proses penguasaan bahasa yang dilakukan oleh anak secara natural pada waktu dia belajar bahasa ibunya (B1) (Darjowidjojo, 2010, hal. 225). Pemerolehan bahasa ibu adalah bahasa pertama yang diperoleh ketika anak usia baru lahir. Anak usia baru lahir diajak ibunya komunikasi menggunakan bahasa pertama. Hal ini dilakukan melalui proses alami.

Bahasa ibu adalah bahasa pertama yang dipelajari anak melalui proses keterampilan berbahasa dimulai sejak bayi. Oleh karena itu, bahasa yang digunakan anak berkomunikasi dipengaruhi oleh latar belakang bahasa ibu yang dikuasainya. Kosakata yang dikuasai anak dipengaruhi lingkungan keluarga. Oleh karena itu, lingkungan keluarga menjadi tempat pemerolehan bahasa pertama bagi anak (Darjowidjojo, 2010, hal. 225). Hal itu tampak, ketika berkomunikasi dengan teman-temannya.

Pada masa anak-anak akhir sudah mengalami peningkatan perbendaharaan kosakata, sehingga penggunaan kata dan kalimat bertambah kompleks serta menyerupai bahasa orang dewasa. Hal ini disebabkan oleh pengaruhi pemberian materi pelajaran di sekolah, yaitu mulai bahan bacaan yang dibaca, dan menyimak pembicaraan orang lain dan radio, serta menonton televisi. Kegiatan itu dilakukan 
sejak kecil atau sebelum masuk sekolah dasar. Atas dasar itu, ketika anak masuk kelas I sudah memiliki perbendaharaan kosakata berjumlah sekitar 20.000 hingga 24.000 kata.Dengan demikian, anak masuk usia sekolah dasar sudah memunyai modal perkembangan bahasa secara signifikan. Lebih-lebih anak usia 11-12 tahun kategori kelas VI Sekolah Dasar tidak hanya menguasai bahasa, melainkan dapat menyusun kata menjadi kalimat menggunakan konjungsi untuk kegiatan menulis karangan. Meskipun hasil menulis karangan berbeda-beda dari tiap anak yang disebabkan oleh kemampuan akademik dan kemampuan kebahasaan berbeda-beda pula. Namun kegiatan menulis itu sebagai bukti bahwa anak usia 11-12 dapat berpikir sistematis dalam mengembangkan ide atau gagasan.

Kenyataan itu meyakinkan peneliti bahwa anak usia 11-12 tahun kategori kelas VI Sekolah Dasar dapat menyusun kalimat sesuai kaidah bahasa. Meskipun beberapa anak menemui kesulitan dan hasil kurang maksimal dalam menyusun kalimat. Namun masalah itu dapat teratasi. Kondisi ini sering dialami anak usia Sekolah Dasar. Lebih-lebih anak kelas VI Sekolah Dasar, meskipun secara tingkat pendidikan sudah dinyatakan mampu menggunakan konjungsi koordinatif dan subordinatif. Atas dasar itu, untuk mengetahui sejauh mana konjungsi yang diperoleh anak dan difungsikan dengan benar, maka peneliti akan membuktikan dalam penelitian.

Secara harfiah istilah konjungsi adalah kata "penghubung" intrakalimat dan antarkalimat. Konjungsi merupakan kata sambung digunakan untuk menggabungkan kata dengan kata, frase dengan frase, klausa dengan klausa, kalimat dengan kalimat, dan paragraf dengan paragraf. Dengan demikian, konsep konjungsi difungsikan sesuai konteks kalimat melalui proses konstruksi kebahasaan berdasar kaidah bahasa Indonesia (Kridalaksana, 2011, hal. 131).

Secara fungsional, konjungsi atau kata penghubung digunakan untuk menyambung dua kata atau antarkalimat. Oleh karena itu, dilihat dari perilaku sintaksis, konjungsi dibagi menjadi empat kelompok: (1) konjungsi koordinatif, (2) konjungsi subordinatif, (3) konjungsi korelatif, dan (4) konjungsi antarkalimat, yang berfungsi pada tataran wacana(Alwi, Dardjowidjojo, Lapoliwa, \& Noeliono, 2003, hal. 297). Namun dalam penelitian ini menggunakan dua konjungsi, yakni konjungsi koordinatif dan konjungsi subordinatif. Alasan dipilihnya dua konjungsi itu, karena anak usia 11-12 kategori siswa kelas VI Sekolah Dasar secara teori sudah mengenal konjungsi sebagaimana yang diajarkan oleh guru.

Berdasar uraian di depan, penggunaan konjungsi koordinatif dan subornitatif yang diterapkan di antarkalimat, antarklausa, ataupun antarparagraf yang terdapat di tiap hasil karangan narasi siswa kelas VI Sekolah Dasar disebut pemerolehan konjungsi. Hasil pemerolehan konjungsi dapat diidentifikasi oleh peneliti. Alasan dipilihnya anak usia 1112 kategori siswa kelas VI Sekolah Dasar yang termasuk usia kelas tinggi sebagai subjek penelitian. Karena secara hakikat proses pembelajaran menulis sudah 
diajarkan dan sesuai dengan Kurikulum, baik KTSP maupun Kurikulum 2013. Hal ini menjadi dasar pemikiran utama bagi peneliti. Selanjutnya, alasan peneliti memilih obyek penelitian pemerolehan konjungsi koordinatif dan konjungsi subordinatif. Karena topik ini menarik untuk diteliti dan sepanjang pengetahuan peneliti belum ada yang meneliti.

Berdasar pada uraian latar belakang, permasalahan dalam pembahasan ini difokuskan menjadi dua masalah, yakni (1) Bagaimanakah pemerolehan konjungsi koordinatif pada anak kelas 6 Sekolah Dasar? (2) Bagaimanakah pemerolehan konjungsisubordinatif pada anak kelas 6 Sekolah Dasar? Adapun tujuan pembahasan yang hendak dicapai adalah (1) mendeskripsikan pemerolehan konjungsi koordinatif pada anak kelas 6 Sekolah Dasar; dan (2) mendeskripsikan pemerolehan konjungsisubordinatif pada anak kelas 6 Sekolah Dasar. Manfaat pembahasan ini adalah (1) dapat memperkaya pengetahuan tentang penggunaan konjungsi koordinatif dan subordinatif yang diterapkan menulis karangan siswa; (2) dapat sebagai dasar untuk penelitian lanjutan, khususnya kajian psikolinguistik, yaitu penelitian tentang pemerolehan bahasa; (3) penelitian ini dapat digunakan untuk referensi dalam melakukan penelitian berikutnya; (4) penelitian ini dapat digunakan untuk referensi, baik bagi guru maupun mahasiswa dalam pembelajaran menulis karangan dengan menggunakan konjungsi koordinatif dan subordinatif; (5) penelitian ini dapat pula menambah wawasan bagi para pembaca. Adapun rencana luaran penelitian dari hasil penelitian ini adalah (1) secara internal hasil dari penelitian ini akan dimasuk ke jurnal Inovasi di Fakultas Bahasa dan Sains dan (2) secara eksternal hasil dari penelitian ini akan dimasukkan seminar nasional Universitas Wijaya Kusuma Surabaya.

\section{METODE PENELITIAN}

Penelitian ini menggunakan metode untuk merumuskan ide dan pikiran berdasar pada pendekatan ilmiah. Proses penelitian ini dimulai pengumpulan, pengolahan sampai pengambilan simpulan dilakukan beberapa tahapan. Jadi, secara holistik, untuk mendeskripsikan bentuk kata-kata dan bahasa dalam konteks khusus alamiah perlu memanfaatkan berbagai metode alamiah (Moleong, 2011, hal. 6). Karena mendeskripsikan fenomena kebahasaan yang terjadi dalam proses belajar Bahasa Indonesia yang dilakukan anak usia 1112 tahun atau kelas 6 Sekolah Dasar dalam bentuk pemerolehan konjungsi koordinatif dan konjungsi subordinatif yang dihasilkan di tiap kalimat dalam hasil karangan tiap anak.

Jenis penelitian ini menggunakan pendekatan kualitatif. Penelitian kualitatif deskriftif digunakan pada data berupa konjungsi koordinatif dan konjungsi subordinatif diperolehdi tiap kalimat berada dalam karangan. Selanjutnya, dianalisis dan hasil analisisnya berbentuk deskriptif fenomena.

Dalam penelitian ini peneliti berperan sebagai instrumen penelitian sekaligus pengumpul data yang dihasilkan dari subjek penelitian. Selain itu, peneliti juga 
Jurnal Belajar Bahasa, ISSN 2502-5864, E-ISSN 2503-0329

Volume 3, No. 2, September 2018

dibantu oleh guru yang berperan membantu peneliti dalam mengajar materi yang terkait dengan menulis karangan dalam bentuk narasi dengan topik pengalaman sendiri. Dalam pengumpulan data, peneliti melakukan sendiri proses indentifikasi di tiap karangan yang dibuat subjek. Peran guru hanya membantu untuk menyampaikan materi konjungsi. Selanjutnya, peneliti juga bertindak sebagai partisipan dalam mengumpulkan data yang dihasilkan dari subjek penelitian.

Lokasi penelitian yaitu di Sekolah Dasar Islam Darut Taqwa jalan Dukuh Kupang XXI no. 24 Surabaya. Sekolah Dasar itu merupakan sekolah swasta full day dan tergolong sekolah dasar menengah ke atas serta berkualitas unggulan. Karena itu, peneliti memilih dan menetapkan Lokasi itu sebagai tempat penelitian.

Pelaksanaan penelitian disesuaikan dengan jadwal mengajar guru mata pelajaran Bahasa Indonesia dan disesuaikan pula urutan materi yang disampaikan oleh guru. Subjek penelitian ini adalah siswa kelas 6 Sekolah Dasar Islam Darut Taqwa Surabaya berusia 11-12 tahun berjumlah 11 . Untuk menentukan usia di masing-masing subjek, peneliti meminta identitas. Setelah identitas diketahui, selanjutnya, peneliti menentukan usia sesuai dengan rumusan penelitian yang sudah ditetapkan peneliti. Perhatikan Tabel 1 untuk subjek penelitian ini.
Tabel 1 Nama Subyek Penelitian Siswa Kelas VI Sekolah Dasar

\begin{tabular}{|l|l|l|l|}
\hline No & $\begin{array}{c}\text { Kode Nama } \\
\text { Siswa }\end{array}$ & $\begin{array}{c}\text { Jenis } \\
\text { kelamin }\end{array}$ & Usia \\
\hline 1. & MHM & $\mathrm{P}$ & 11 \\
\hline 2. & SAPP & $\mathrm{P}$ & 12 \\
\hline 3. & SAL & $\mathrm{P}$ & 12 \\
\hline 4. & CAP & $\mathrm{P}$ & 11 \\
\hline 5. & AWA & $\mathrm{L}$ & 11 \\
\hline 6. & BRP & $\mathrm{L}$ & 12 \\
\hline 7. & AY & $\mathrm{L}$ & 12 \\
\hline 8. & AD & $\mathrm{L}$ & 12 \\
\hline 9. & $\mathrm{AFF}$ & $\mathrm{L}$ & 12 \\
\hline 10. & $\mathrm{AB}$ & $\mathrm{L}$ & 11 \\
\hline 11. & $\mathrm{PP}$ & $\mathrm{P}$ & 11 \\
\hline
\end{tabular}

Berdasar pada tabel 1 pemilihan subjek dilakukan sesuai dengan jenis dan karakter penelitian ini. Oleh karena itu, pemilihan subjek dilakukan melalui pertimbangan sebagai berikut.

a. Sehat jasmani dan rohani

b. Mampu menulis (membuat karangan) dengan baik.

c. Usia 11-12 tahun.

d. Mampu menggunakan Bahasa Indonesia dengan baik dan benar, ketika menulis.

Korpus data penelitian ini berupa konjungsi koordinatif dan konjungsi subordinatif. Kedua konjungsi tersebut diperoleh melalui hasil karangan (tulisan) siswa kelas 6 SD berjumlah 4. Dengan demikian, tiap subjek menghasilkan 4 karangan (tulisan), jadi secara keseluruhan berjumlah 44 karangan. Karangan ditulis oleh subjek, berupa menceritakan pengalaman sendiri dalam bentuk narasi.

Data yang diperoleh dari tugas mengarang sesuai pengalaman sendiri sudah tersusun secara berurutan, kemudian dianalisis dengan prosedur sebagai berikut. 
Jurnal Belajar Bahasa, ISSN 2502-5864, E-ISSN 2503-0329

Volume 3, No. 2, September 2018

1. Pengidentifikasian data

Setelah tulisan karangan terkumpul, tahap selanjutnya pengidentifikasian data. Data yang diidentifikasi peneliti adalah kalimat ditulis subjek yang didalamnya terdapat penggunaan konjungsi konjungsi koordinatif atau subordinatif.

2. Pengklasifikasian data

Data sudah terkumpul, kemudian diklasifikasikan berdasar rumusan masalah, yaitu konjungsi apa sajakah yang digunakan dalam proses pemerolehan bahasa.

3. Pengkodean data

Konjungsi yang telah dipisahkan diberi kode dengan aturan sebagai berikut: kode $A 12$, kode $A$ menyatakan nama subjek penelitian, kode I romawi menyatakan karangan yang dihasilkan, dan kode 2 menyatakan konjungsi pada kalimat keberapa.

$\begin{array}{ccc}\text { Penelitian } & \text { kualitatif } & \text { dalam } \\ \text { pengumpulandata } & \text { dilakukan } & \text { secara }\end{array}$

natural setting (Sugiyono, 2009, hal. 63). Karena teknik pengumpulan data lebih banyak menggunakan teknik dokumentasi, tetapi peran observasi juga dilakukan. Teknik dokumentasi digunakan menjaring data. Studi dokumentasi ini merupakan kegiatan utama yang dilakukan oleh peneliti dengan memberikan tugas menulis karangan. Teknik observasi dilakukan sebelum pengambilan data di tiap subjek.

Instrumen yang digunakan dalam penelitian ini, yaitu lembar tugas untuk menulis karangan diberikan di tiap subjek satu persatu. Hal itu, dilakukan oleh guru kelas. Setelah itu guru mengarahkan subjek menulis karangan di lembar tugas dengan tema berbeda-beda di tiap subjek. Meskipun demikian, peneliti juga sebagai instrumen membantu guru kelas untuk mencatat periode pengambilan data.

Proses analisis data dilakukan melalui dua tahapan, yaitu: 1) kategorisasi, 2) tabulasi. Kategorisasi meliputi kategorisasi konjungsi, merupakan pengkategorian data berdasar pada konjungsi koordinatif dan subordinatif. Proses selanjutnya adalah tabulasi. Tabulasi merupakan penyajian data dalam bentuk tabel. Tabulasi tersebut berupa tabel tentang bentuk konjungsi beserta fungsinya.

Analisis data melalui beberapa tahap atau proses pada penelitian ini memiliki dua fungsi. Fungsi pertama adalah untuk menentukan bentuk konjungsi koordinatif dan subordinatif. Fungsi kedua adalah untuk menentukan fungsi dari bentuk konjungsi koordinatif dan subordinatif.

\section{PEMBAHASAN}

\section{A. Pemerolehan Konjungsi}

Pemerolehan konjungsi merupakan pemerolehan kata penghubung bahasa Indonesia yang dihasilkan langsung dari anak, ketika komunikasi berlangsung, baik secara tulis maupun lisan. Pemerolehan konjungsi pada tiap anak bervariasi, kadang-kadang sesuai dengan dua kalimat yang dihubungkan antara frasa yang satu dengan yang lainnya dan antara kalimat satu dengan yang lainnya pula. Karena itu, pemerolehan konjungsi dapat pula muncul, baik di bahasa pertama maupun bahasa kedua, bergantung pada penggunaan bahasa yang digunakan ketika komunikasi berlangsung. Artinya, 
konjungsi itu digunakan oleh anak, baik sudah terkonsep ataupun tidak.

"acqusition is a subconscious process that is identical to the process used in the first language acquistion in all important ways"(Krashen, 1989, hal. 8).

Artinya, bahwa pemerolehan merupakan proses bawah sadar yang identik dengan proses yang digunakan dalam pemerolehan bahasa pertama diberbagai kepentingan. Pemerolehan bahasa yang dialami anak, yaitu melalui proses tidak sengaja, tetapi proses tersebut dapat menghasilkan bahasa sesuai keinginan.

Konjungsi berfungsi untuk meluaskan satuan yang lain dalam konstruksi hipotaktis dan selalu menghubungkan dua satuan lain atau lebih dalam konstruksi. Konjungsi juga disebut kata sambung adalah kata tugas yang menghubungkan dua satuan bahasa yang sederajat: kata dengan kata, frasa dengan frasa, atau klausa dengan klausa(Alwi, Dardjowidjojo, Lapoliwa, \& Noeliono, 2003, hal. 296).

Dari beberapa pendapat dapat dipahami bahwa kata konjungsi merupakan kata yang berfungsi sebagai kata penghubung, baik antarkalimat, dalam kalimat, antarklausa, antarfrasa maupun dalam bentuk kata. Berikut perhatikan contoh penggunaan konjungsi pada kata dengan kata, frasa dengan frasa, atau klausa dengan klausa.

Jika dilihat dari posisinya, konjungsi dapat dirinci menjadi dua macam, yaitu konjungsi intrakalimat dan konjungsi ekstrakalimat. Konjungsi intrakalimat terdiri atas konjungsi antarkata, antar frasa, dan antarklausa seperti pada contoh di atas. Sedangkan konjungsi ekstrakalimat terdiri atas konjungsi antar kalimat atau paragraf. Dilihat dari perilaku sintaksisnya, konjungsi dibagi menjadi empat kelompok: (1) konjugsi koordinatif, (2) konjungsi korelatif, (3) konjungsi subordinatif, dan (4) konjungsi antarkalimat, yang berfungsi pada tataran wacana (Alwi, Dardjowidjojo, Lapoliwa, \& Noeliono, 2003, hal. 297).

\section{1) Pemerolehan Konjungsi Koordinatif}

Konjugsi Koordinatif, yaitu kata penghubung yang menghubungkan dua klausa atau lebih yang memiliki status sederajat, di antaranya dan, atau, tetapi, sedangkan, melainkan, lalu, kemudian, padahal (Moeliono, 1988, hal. 68).

Konjungtor koordinatif merupakan konjungsi menghubungkan dua unsur atau lebih dansama pentingnya, atau memiliki status sama (Alwi, Dardjowidjojo, Lapoliwa, \& Noeliono, 2003, hal. 287). Berikut penanda konjungsi koordinatif.

dan penanda hubungan penambahan serta penanda hubungan pendamping atau penanda hubungan pemilihan tetapi penanda hubungan perlawanan melainkan penanda hubungan perlawanan

padahaldan sedangkan penanda hubungan pertentangan

Terdapat empat penanda sintaksis hubungan koordinatif. Berikut penjelasan di tiap penanda (Alwi, Dardjowidjojo, Lapoliwa, \& Noeliono, 2003, hal. 393).

(a) Hubungan koordinasi menggabungkan dua klausa atau lebih. Di samping itu, satu di antara klausa yang dihubungkan oleh konjungsi 
Jurnal Belajar Bahasa, ISSN 2502-5864, E-ISSN 2503-0329

Volume 3, No. 2, September 2018

koordinatif dapat berupa kalimat majemuk.

(b) Pada umumnya posisi klausa yang diawali oleh koordinator dan, atau, dan tetapi tidak dapat diubah. Apabila posisinya diubah, perubahan itu mengakibatkan munculnya kalimat majemuk setara yang tidak berterima.

(c) Sebuah koordinator dapat didahului oleh koordinator lain untuk memperjelas atau mempertegas hubungan antara kedua klausa yang digabungkan. Perhatikan kalimat berikut ini.

(d) Ciri semantis dalam hubungan koordinatif ditentukan oleh makna dari macam koordinatif yang dipakai dan makna leksikal ataupun gramatikal dari kata dan klausa yang dibentuk. Koordinatif dan, misalnya, menyatakan gabungan antarklausa. Sebaliknya, koordinator tetapi menyatakan pertentangan (Alwi, Dardjowidjojo, Lapoliwa, \& Noeliono, 2003, hal. 397).

Konjungsi koordinatif berbeda dengan konjungsi lainnya. Karena konjungsi tersebut, selain dapat menghubungkan klausa, juga dapat menghubungkan kata. Meskipun demikian, frasa yang dihasilkan bukanlah frasa prepoposional. Perhatikan contoh penggunaan konjungsi koordinatif.

(1) Di Surabaya banyak sekali kendaraan-kendaraan dan gedunggedung tinggi yang berkaca. (AD/II/KPS/4)

(2) Kapal Selam juga bisa berguna untuk tempat rekreasi atau hiburan anak. (AB/III/MKS/11)

(3) Kemudian Kota Surabaya termasuk kota yang beriman tetapi, warga- warga kota Surabaya semakin tidak beriman. (CAP/II/KPS/8)

Pada (1) konjungsi dan difungsikan untuk menyebutkan dua kata benda, yaitu kendaraan-kendaraan dan gedunggedung. Koordinatif dan menyatakan gabungan antarklausa yang menunjukkan penguatan atau penegasan. Pemakaian konjungsi atau pada kalimat (2) membahas pemilihan dua kata tempat antara rekreasi dan hiburan. Kalimat (3) koordinator tetapi menyatakan pertentangan membahas slogan kota Surabaya yang tidak sesuai dengankondisireligius warganya. Berikut perhatikan contoh di bawah ini.

(4) Bunga berfungsi untuk menghias taman sedangkan pohon berfungsi untuk menghijaukan taman agartetap rindang dan indah (AY/I/TPK/5)

(5) Apabila musim libur datang banyak orang yang datang biasanya mereka membawa serta keluarga mereka. (PP/III/MKS/8)

Pemakaian konjungsi sedangkan pada (4) tersebut benar, karena antara kalimat pertama bunga berfungsi untuk menghias taman merujuk pada kalimat pohon berfungsi untuk menghijaukan taman. Pada kutipan (5) tersebut salah, kesalahan itu terletak pada susunan kalimat yang kurang jelas, misalnya biasanya mereka membawa serta keluarga mereka.

Berdasar pada uraian pembahasan terkait pemerolehan konjungsi koordinatif. Hasil pemerolehan konjungsi koordinatif yang terdapat di karangan 
Jurnal Belajar Bahasa, ISSN 2502-5864, E-ISSN 2503-0329

Volume 3, No. 2, September 2018

siswa kelas VI, meliputi sedangkan, dan, tetapi, serta, atau, kemudian.

\section{2) Pemerolehan Konjungsi Subordinatif}

Konjugsi Subordinatif yaitu kata penghubung yang menghubungkan dua klausa atau lebih yang tidak sama derajatnya, di antaranya ketika, sejak, kalau, jika, supaya, biar, seperti, sehingga, setelah, andai, bagai, ibarat, karena(Moeliono, 1988, hal. 67).

Konjungsi subordinatif merupakan konjungsi yang menghubungkan dua klausa, atau lebih, dan klausa itu tidak memiliki status sintaksis yang(Alwi, Dardjowidjojo, Lapoliwa, \& Noeliono, 2003, hal. 287). Satu di antaranya dari klausa itu merupakan anak kalimat, jika dilihat dari perilaku sintaksis dan semantiknya. Konjungsi subordinatif dapat dibagi menjadi tiga belas kelompok. Berikut adalah kelompok konjungsi subordinatif.

(a) Konjungsi subordinatif waktu: sejak, semenjak, sewaktu, ketika, tatkala, setelah, sesudah, hingga, sampai, dan lain sebagainya.

(b) Konjungsi subordinatif syarat: jika, kalau, jikalau, asal(kan), bila, manakala.

(c) Konjungsi subordinatif pengandaian: andaikan, seandainya, umpamanya, sekiranya.

(d) Konjungsi subordinatif tujuan: agar, supaya, biar.

(e) Konjungsi subordinatif konsesif: biarpun, meski(pun), walau(pun), sekalipun, sungguhpun, kendati (pun).

(f) Konjungsi subordinatif pembandingan: seakan-akan, seolah-olah, seperti, laksana, ibarat, daripada, alih-alaih, dan lain sebagainya.

(g) Konjungsi subordinatif sebab: sebab, karena, oleh karena, oleh sebab.

(h) Konjungsi subordinatif hasil: sehingga, sampai (-sampai), maka (nya).

(i) Konjungsi subordinatif alat: dengan, tanpa.

(j) Konjungsi subordinatif cara: dengan, tanpa

(k) Konjungsi subordinatif komplementasi: bahwa.

(I) Konjungsi subordinatif atributif: yang.

(m) Konjungsi subordinatif perbandingan: sama ... dengan, lebih ...dari(pada)

Ciri-ciri sintaksis dalam hubungan subordinatif adalah sebagai berikut(Alwi, Dardjowidjojo, Lapoliwa, \& Noeliono, 2003, hal. 395).

(a) Subordinasi menghubungkan dua klausa satu dari beberapa bagian dari klausa lain. Di samping itu, satu di antara klausa yang dihubungkan oleh konjungtor subordinatif dapat pula berupa kalimat majemuk.

(b) Pada umumnya posisi klausa yang diawali oleh subordinator dapat berubah.

(c) Hubungan subordinatif memungkinkan adanya acuan kataforis. Dalam kalimat "Walaupun dia suka lagu keroncong, Hasan tidak mau membeli kaset itu", pronomina dia dapat mengacu pada nomina nama diri Hasan walaupun tidak harus demikian.

(d) Secara semantis, klausa yang mengikuti konjungsi subordinatif memuat informasi atau pernyataan yang dianggap sekunder oleh pemakai bahasa, sedangkan klausa yang lain 
memuat pesan yang utama. Di samping itu, karena klausa yang mengikuti konjungsi subordinasi itu bersifat melengkapi atau menerangkan klausa yang lain, maka secara semantis klausa itu dapat disubstitusi dengan frasa yang menduduki fungsi keterangan atau komplemen klausa lain(Alwi, Dardjowidjojo, Lapoliwa, \& Noeliono, 2003, hal. 397).

Dalam konjungsi subordinatif terdapat pula beberapa kata yang juga termasuk dalam kategori kata depan atau preposisi. Perhatikan kalimat (6) di bawah ini.

(6)Saya sangat setuju sekali dengan adanya Monkasel karena Monkasel dapat menjadi tempat rekreasi keluarga yang nyaman sekaligus menambah wawasan kita. (PP/III/MKS/8)

Kalimat (6) memberikan alasan yang berkaitan dengan keberadaan Monkasel untuk rekreasi dan menambah wawasan. Kata karena yang dapat diikuti oleh klausa dianggap sebagai konjungsi dan kata yang dapat diikuti oleh kata dianggap sebagai kategori preposisi

(7)kita harus datang ke Monkasel agar menambah wawasan kita dan kita serasa naik kapal selam sungguhan. (BRP/III/MKS/9)

(8)Kota Surabaya juga selalu mengadakan acara "Green and Clean" supaya Kota Surabaya tetap bersih dan hijau. (SAL/II/KPS/4)

(9)Pohon-pohon yang ditanam di sepanjang jalan akan membantu mengurangi tingkat polusi sehingga, bumi menjadi hijau kembali. (PP/I/TPK/3)
Kalimat (7) konjungsi agar menyatakan tujuan yang kalimatnya berisi tentang ajakan untuk melakukan sesuatu. Pemakaian konjungsi agar ditemukan tiga ditahap yang berbeda, antara tahap satu dan tahap tiga.Kalimat (8) Konjungsi supaya digunakan menyatakan bertujuan untuk mengajak masyarakat agar tetap menjaga kebersihan. Kalimat (9) konjungsi sehingga menunjukkan hubungan hasilan, yaknikata pohon-pohon yang ditanam di bumi bisa menghasilkan bumi menjadi hijau,

Berdasar pada uraian pembahasan terkait pemerolehan konjungsi subordinatif. Berikut hasil pemerolehan konjungsi subordinatif yang terdapat di karangan siswa kelas VI, meliputi oleh karena itu, oleh sebab itu, setelah itu, yang, setelah, sesudah, sehingga, hingga, agar, supaya, ketika, sampai, walaupun, meski, maka, seperti, karena, kalau, asal.

\section{B. Anak Usia 11-12 tahun (Kelas 6 Sekolah Dasar)}

Pada anak usia antara 11 atau 12 tahun kalau digolong pada tingkat pendidikan formal, yakni kelas VI Sekolah Dasar. Anak menduduki kelas VI Sekolah Dasar termasuk kelas tinggi. Khusus bagi anak yang normal, yakni anak kelas VI Sekolah Dasar miliki pengetahuan cukup luas, sehingga berdampak terhadap cara berpikir dan cara mengambil keputusan. Bahkan, dari segi kematangan berbahasa dikategorikan baik atau lancar, terutama bahasa lisan, lebih-lebih bahasa tulis. Jika diperintahkan oleh guru untuk membuat sebuah karya tulis berupa karangan berdasar pada pengalamannya sendiri, maka anak tersebut bisa menarasikan dari 
apa yang dialami dan dilihat langsung di lingkungan sekitar. Karangan yang dihasilkan tersebut tampak kalimat yang runtut dan sistematis. Hal itu disebut pemerolehan bahasa, khususnya konjungsi terutama konjungsi koordinatif dan konjungsi subordinatif yang diperoleh di tiap kalimat yang ada di karangan.

Taylor menyatakan bahwa ada enam fase perkembangan bahasa anak, khususnya anak kelas VI Sekolah Dasar tergolong fase anak sekolah (usia 6-12 tahun) (Ellis, 1994, hal. 228). Padaanak usia ini sudah terampil mengkomunikasikan ide mereka melalui kalimatkalimat dan diskursus dengan struktur bahasa bervariasi dan kompleks. Mereka juga mempelajari keterampilan berbahasa lain, seperti membaca dan menulis yang selanjutnya memiliki peran penting terhadap perkembangan intelektual mereka.

\section{Pemerolehan Konjungsi dikaji dalam Perpektif Psikolinguistik}

Bahasa dapat dilihat dari berbagai perspektif, satu di antaranya perspektif psikolinguistik. Psikolinguistik adalah studi mengenai penggunaan bahasa dan pemerolehan bahasa yang dialami manusia. Dua studi itu membagi Psikolinguistik menjadi tiga bidang utama bagaimana cara melihat bahasa itu diperoleh antara lain, Psikolinguistik Umum, Psikolinguistik Perkembangan, dan Psikolinguistik Terapan. Kajian-kajian psikolinguistik itu berhubungan erat dengan pemerolehan bahasa dari segi struktur bahasa, fungsi bahasa, dan proses pemerolehan bahasa, serta paling penting adalah bagaimana mengajarkan bahasa asing kepada anak. Seorang anak belajar bahasa dalam perspektif psikolinguistik disebut pemerolehan bahasa.

Dalam pemerolehan sebuah bahasa tidak lepas dari tiga aspek penting antara lain, (1) pemerolehan bahasa dipengaruhi oleh aspek internal dan bisa dikatakan kembali lagi kepada individu masingmasing; (2) lingkungan (aspek eksternal) juga dapat mempengaruhi terhadap pemerolehan bahasa; (3) bahasa secara natural manusia sudah memiliki daya atau kemampuan berbahasa (Ingram, 2007, hal. 46). Tiga aspek dari pendapat Ingram menunjukkan bahwa pemerolehan bahasa, baik tidaknya bergantung pada individu masing-masing, itupun khusus bagi anak yang normal. Sebaliknya, bagi anak yang memiliki kekurangan terkait dengan fisik, maka mengalami kesulitan. Selain itu, aspek penting pendapat Ingram terkait psikolinguistik terdapat dua aspek, yaitu bagaimana orang terutama anakanak belajar bahasa dan penggunaan bahasa. Maksud dua aspek itu, yakni bagaimana orang dewasa normal menggunakan bahasa (Mar'at, 2011, hal. 114).

Pendapat levelt yang dikutip Mar'at menjelaskan tentang pemerolehan bahasa, kalau dikaitkan dengan pemerolehan konjungsi dalam perspektif psikolinguistik merupakan kajian pemerolehan kata sambung atau kata penghubung, baik antarkata dengan kata, maupun antarkalimat dengan kalimat yang dihasilkan dari belajar bahasa, kemudian kata penghubung itu digunakan 
Jurnal Belajar Bahasa, ISSN 2502-5864, E-ISSN 2503-0329

Volume 3, No. 2, September 2018

di bahasa tulis berupa karangan melalui proses pembelajaran menulis. Hal ini menunjukkan cara proses berpikir anak, ketika proses menulis berlangsung. Usaha sadar anak merangkai kata menjadi kalimat dengan menentukan satu konjungsi, kemudian konjungsi itu difungsikan sesuai dengan karakter kalimat. Semua itu bergantung jenis kalimat yang ditulis.

\section{SIMPULAN}

Berdasarkan hasil pembahasan dalam penelitian ini. Konjungsi yang dikuasai atau sering digunakan siswa kelas VI dalam tulisan karangan terdapat dua, yakni konjungsi koordinatif dan konjungsi subordinatif perinciannya sebagai berikut. Hasil penelitian (1) pemerolehan konjungsi koordinatif terdapat di karangan siswa kelas VI, meliputi sedangkan, dan, tetapi, serta, atau, kemudian. (2) pemerolehan konjungsi subordinatif terdapat di karangansiswa kelas VI, meliputi oleh karena itu, oleh sebab itu, setelah itu, yang, setelah, sesudah, sehingga, hingga, agar, supaya, ketika, sampai, walaupun, meski, maka, seperti, karena, kalau, asal.

\section{DAFTAR RUJUKAN}

Alwi, H., Dardjowidjojo, S., Lapoliwa, H., \& Noeliono, A. M. (2003). Tata Bahasa
Baku Bahasa Indonesia (Third ed.). Jakarta: Balai Pustaka.

Darjowidjojo, Soejono. (2010).

Psikolinguistik: Pengantar

Pemahaman Bahasa Anak Indonesia. Jakarta: Yayasan Obor Indonesia.

Ellis, Rod. (1994). The Study of Second Language Acquisition. Oxford:

Blackwell.

Ingram, John C. L. (2007). Neurolinguistics

An Introduction to Spoken language Processing and its Disorders. New York: Cambridge University Press.

Krashen, Stephen D. (1989). Language Acquisition and language Education, Extension and Application, Prentice Hall International, BPCC Wheatons Ltd. Exeter.

Kridalaksana, Harimurti. (2011). Kamus Linguistik. Jakarta: PT Gramedia.

Mar'at, Samsunuwiyati. (2011).

Psikolinguistik Suatu Pengantar.

Bandung: Refika Aditama.

Moeliono, Anton M. (1988). Tata Bahasa

Baku Bahasa Indonesia. Jakarta: Balai Pustaka.

Moleong, Lexi J. (2011). Metodelogi Penelitian Kualitatif. Bandung: Remaja Rosdakarya.

Sugiyono. (2009). Metode Penelitian Kuantitatif, Kualitatif dan $R \& D$. Bandung: Alfabeta. 